\title{
A STUDY ON WORK LIFE BALANCE OF WOMEN PROFESSORS WORKING IN SELECTED COLLEGES IN CHENNAI CITY
}

\author{
Dr. A. Irin Sutha \\ Assistant Professor, Department of CS \& AF, \\ Faculty of Science and Humanities, SRM IST, India
}

\begin{abstract}
This study enlists certain dimensions and its implications over work life balance were identified. It also learnt from the present study that managing work life balance is channelized by the psychological makeup of an individual's especially women and that is purely as an attitude based issue. Therefore, the study concludes that work life balance practices improve the quality of work life of working women. Now the women's are occupy almost all categories of positions in the workplace. Among other occupations, teaching is reported to have positive and negative experiences about work life. The paper takes an in-depth look at work life balance considering in view of Balance in work and family life is an emerging challenge for both employees and employers.
\end{abstract}

Key word: Work Life, Women, Professors Working, College

Cite this Article: Dr. A. Irin Sutha, A Study on Work Life Balance of Women Professors Working in Selected Colleges in Chennai City, International Journal of Management, 10 (4), 2019, pp. 159-167.

http://iaeme.com/Home/issue/IJM?Volume=10\&Issue $=4$

\section{INTRODUCTION}

The concept of work life balance has stemmed from the fact that an individual's work life and personal life may put forth conflicting demands on one another and the demands from both the domains are equally important. Work life balance refers to maintaining the balance between responsibilities at work and at home. Work life balance is one of the most challenging issues being faced by the women employees in the 21 st century because of the type of roles they play at home and the spillover of personal life over work life.

This study enlists certain dimensions and its implications over work life balance were identified. It also learnt from the present study that managing work life balance is channelized by the psychological makeup of an individual's especially women and that is purely as an attitude based issue. Therefore, the study concludes that work life balance practices improve the quality of work life of working women. Now the women's are occupy almost all categories of positions in the workplace. Among other occupations, teaching is reported to have positive and negative experiences about work life. The paper takes an in-depth look at 
work life balance considering in view of Balance in work and family life is an emerging challenge for both employees and employers. The present research categorizes selected variables as work and family related factors to study work life balance. This paper analyzes the causes of work and life imbalance with respect to women professors. A total of 50 respondents from various colleges and institutes in Chennai are included in this study. Statistical analysis reveals that the main cause of imbalance of work life balance is Heavy work \& extent working hours followed by inabilities to priorities and manages time and Flexi - time, reduced working hours \& other facilities at working place leads to achieve work life balance.

\section{STATEMENT OF THE PROBLEM}

There have been prolonged debates for decades together that working women developed more optimistic attitude towards their life than the housewife. They are mostly economically independent and mostly not depend on husbands finance. This raises questions in the mind of the researcher that whether daunting job of being a working women leads to stress in the form of fatigue, anxiety, etc while balancing their household chores. If yes what are causes for the stress and the level of stress. Hence this study is undertaken to identify the most important factors contributing towards stress among sample respondent college teachers.

\subsection{Components of Work Life Balance}

\section{Self-Management}

Sufficiently managing one's self can be challenging, particularly in getting proper sleep, exercise, and nutrition. Self-management is the recognition that effectively using the spaces in our lives is vital, and that available resources, time, and life are finite.

\section{Time Management}

Effective time management involves making optimal use of a day and the supporting resources that can be summoned -keep pace when resources match the challenges. Time management is enhanced through appropriate goals and discerning what is both important and urgent, versus important or urgent. It entails knowing what to do best and when, and assembling the appropriate tools to accomplish specific tasks.

\section{Stress Management}

By nature, societies tend to become more complex over time. In the face of increasing complexity, stress on the individual is inevitable. More people, distractions, and noise require each of us to become adept at maintaining tranquillity and working ourselves out of pressurefilled situations. Most forms of multi-tasking ultimately increase stress, versus focusing on one thing at a time.

\section{Change Management}

In our fast-paced world, change is virtually the only constant. Continually adopting new methods and re-adapting others is vital to a successful career and a happy home life. Effective change management involves making periodic and concerted efforts to ensure that the volume and rate of change at work and at home does not overwhelm or defeat.

\section{Technology Management}

Effectively managing technology means ensuring that technology serves you, rather than abuses you. Technology has always been with us, since the first walking stick, flint, spear, and wheel. Now, the rate of change is accelerating, brought on by vendors seeking expanding market share. 


\section{Leisure Management}

The most overlooked of the work-life balance supporting disciplines, leisure management acknowledges the importance of rest and relaxation- that one can't short-change leisure, and that "time off" is a vital component of the human experience. Curiously, too much of the same leisure activity, however enjoyable, can lead to monotony. Thus, effective leisure management requires varying one's activities.

\subsection{Ways to Improve Work-Life Balance:}

\section{Recognize the role of work}

Work plays a significant part in life. It keeps the lights on, pays the mortgage, makes the car payment, funds retirement and permits yearly vacations, Newcombe said. Adopting the right mind-set allows you to celebrate and enjoy the fruits of your labour, rather than making your job seem like endless drudgery.

\section{Don't be afraid to unplug}

We live in a connected world that never sleeps. Turning off from the outside world provides time to recover from weekly stress. "It also gives us space to let other thoughts and ideas surface. When you are always on, you don't allow other things to surface that might be more important," Stone said. "I meditate each morning for 10 minutes, which provides me with a great start to my day."

\section{Create (and stick to) a daily routine}

While being good at your job is important, it shouldn't be in entire life. An individual before taking this position and should prioritize those activities or hobbies that made happy.

\section{Take vacation}

Sometimes making time for taking a vacation and shutting work completely off."A vacation could be a 15-minute walk around the block without looking at the phone, or a vacation could be two or three weeks travelling with family/friends," Stone said. "It's important to take a step back to physically and mentally recharge. If surrounded by good people at work, a vacation should be easy to take."

\section{Be present, consistent and accountable}

Being present requires being attentive at home, at work and during free time, Woods said."It's so easy to get caught up working, but it's so important to spend time with family, friends or other people who bring joy into our lives," Stone said. "Though it might not seem obvious at first, the memories that create while spending time with that love help spark new ideas, and ways of thinking."

\section{SCOPE OF THE STUDY}

The study can be given a due thought by the institutional heads. Then, as per the suitability of the needs and availability of resources, each institution can prioritize and implement these recommendations for minimizing stress in their faculty members these leads such a work life balance among women teachers in any education institutions.

\section{REVIEW OF LITERATURE}

Pleck's et al, (1977) with the sample consisting of employees of 20 Fortune 500 companies; 28 percent of the men and 53 percent of the women reported that work-family stress affected their ability to concentrate at work hence revealing that more than half the women and almost a third of the men reported that work/family stress affected their ability to concentrate on the job. Life at work seems so difficult for working women, they also stated in his survey results 
on work life balance in Hong Kong quotes that there is an alarmingly high percentage of respondents who feel that work is the cause of health problems, specifically stress and lack of exercise. Health problems are likely lead to lower productivity and effectiveness of workers. This paper focuses on the tough life of married working women of Pondicherry in their battle to strike a balance between work and family life.

Near et al, (1989) studied the feasible ways in which work and life away from work are connected among university faculty members. This study identifies differences on the basis of rank and gender, and also suggests implication of family friendly policies for institutions of higher education, they examined how gender and other implication turns to be stress on the teaching profession that has different dimensions such as pattern of work, authority, identification and career etc, and most important thing is that all these dimensions differ with different institutes and subjects that is why this field is most preferred for Work family conflict.

Sekharan et al, (1992) Work-life balance is a key issue in all types of employment as dual-career families have become common and high work demands with long working hours have become the norm. The importance of helping employees achieve a balance between the demands of their work and their home lives has been emphasized. Demographic changes as seen in the increasing number of women in the workplace and dual career families have generated an increasingly diverse workforce and a greater need of employees to balance their work and non-work lives, their Research reveals the demographic profile of work life balance of women in India, family-to-work spill-over is stronger for women and the work-to-family spill-over is stronger for men. Research suggests that female respondents in all parts of the world are pressured for time, rarely have time to relax and feel stressed and overworked most of the time, but women in emerging countries feel the strain even more so than women in developed countries. Women in India (87\%) are most stressed/pressured for time.

Kofodimos et al, (1993) suggests that imbalance — in particular work imbalance - arouses high levels of stress, detracts from quality of life, and ultimately reduces individuals' effectiveness at work. They suggested that an equally high investment of time and involvement in work and family would reduce work-family conflict and stress thereby enhancing an individual's quality of life. And so it goes without saying that married working women of this era can have a healthy quality of life only when work-life balance is maintained making the topic of work life balance for working women, the need of the hour.

Acker et al, (1996) Sample researches were conducted on teachers Work life balance as it has been found that teaching is a stressful profession. Another most important reason for studying teachers on the aspect of Work life balance is that, this is the profession that has overwhelmingly female than in any other profession, they examined that how Professors put in very long hours. It has been found that full-time male faculty work 54.8 hours per week on an average; their female counterparts report working almost 52.8 hours per week. Faculty members work more hours per week than in most other occupations. Indeed, professors account for longer work week than do most of their counterparts in white collar occupations.

\section{OBJECTIVES OF THE STUDY}

- To know the Demographic profile of the respondents.

- To know the level of work life balance among working women faculties.

- To determine the factors affecting work life balance. 


\section{Dr. A. Irin Sutha}

\section{RESEARCH METHODOLOGY}

\section{Sample Area}

The sample related to the present study basically includes the entire population of Faculties from Arts and Sciences \& Engineering institutions all over Chennai. But the potential respondents (element) are basically selected from different colleges. The potential respondents for this study they're academicians from all genres like Lecturer, Assistant Professors, Associate Professors and Professors.

\section{Sample Size}

The questionnaire was distributed to the women faculty of the various colleges in person. A total of 50 questionnaires were collected.

\section{Data Collection}

- Primary data was collected by questionnaire survey method.

- Secondary data was collected from Journals and Research articles to support the research.

\section{DATA ANALYSIS AND INTERPRETATION}

\begin{tabular}{|c|c|c|}
\hline \multicolumn{3}{|c|}{ Demographic Profile } \\
\hline Age & Frequency & Percentage \\
\hline $22-25$ & 4 & $8 \%$ \\
\hline $26-30$ & 23 & $46 \%$ \\
\hline $31-40$ & 15 & $30 \%$ \\
\hline $41 \&$ Above & 8 & $16 \%$ \\
\hline Total & 50 & $100 \%$ \\
\hline Occupation & Frequency & Percentage \\
\hline Guest Lecturers & 7 & $14 \%$ \\
\hline Assistant Professor & 27 & $54 \%$ \\
\hline Associate Professor & 13 & $26 \%$ \\
\hline Professor & 3 & $6 \%$ \\
\hline Total & 50 & $100 \%$ \\
\hline Educational Qualification & Frequency & Percentage \\
\hline Graduate & 5 & $10 \%$ \\
\hline Post Graduate & 14 & $28 \%$ \\
\hline M.Phil & 20 & $40 \%$ \\
\hline Ph.D & 11 & $22 \%$ \\
\hline Total & 50 & $100 \%$ \\
\hline Monthly Income & Frequency & Percentage \\
\hline Less than 50,000 & 20 & $40 \%$ \\
\hline $50,001-1,00,000$ & 22 & $44 \%$ \\
\hline $1,00,001-1,50,000$ & 5 & $10 \%$ \\
\hline $1,50,001 \&$ Above & 3 & $6 \%$ \\
\hline Total & 50 & $100 \%$ \\
\hline
\end{tabular}

\section{Interpretation}

The above table shows that $46 \%$ of the respondents are in $26-30$ age group, $54 \%$ of the respondents are working has an assistant professor, $40 \%$ of the respondents are qualified Master of Philosophy and 44\% of the respondents are earning 50,001 $-100,000$. 
Chi-square between factors of level of work life balance among working women faculties, factors affecting work life balance, overall level of work life balance among working women faculties and overall factors affecting work life balance

Null Hypothesis: There is no association between Age and factors of level of work life balance among working women faculties

Null Hypothesis: There is no association between Age and factors affecting work life balance

Null Hypothesis: There is no association between Age and overall level of work life balance among working women faculties

Null Hypothesis: There is no association between Age and overall factors affecting work life balance

\begin{tabular}{|c|c|c|c|c|c|c|c|c|}
\hline \multicolumn{9}{|c|}{ 1. I can devote sufficient time for household responsibilities } \\
\hline Age & SA & $\mathbf{A}$ & $\mathbf{N}$ & DA & SDA & Total & Chi-square & P value \\
\hline $22-25$ & 3 & 1 & 0 & 0 & 0 & 4 & \multirow{5}{*}{4.673} & \multirow{5}{*}{0.862} \\
\hline $26-30$ & 11 & 6 & 3 & 3 & 0 & 23 & & \\
\hline $31-40$ & 9 & 2 & 3 & 1 & 0 & 15 & & \\
\hline 41\&Above & 4 & 3 & 1 & 0 & 0 & 8 & & \\
\hline Total & 27 & 12 & 7 & 4 & 0 & 50 & & \\
\hline \multicolumn{9}{|c|}{ 2. I can manage my personal \& professional life well } \\
\hline Age & SA & A & $\mathrm{N}$ & $\mathrm{DA}$ & SDA & Total & Chi-square & $\mathrm{P}$ value \\
\hline $22-25$ & 2 & 0 & 1 & 1 & 0 & 4 & \multirow{5}{*}{24.296} & \multirow{5}{*}{0.019} \\
\hline $26-30$ & 0 & 10 & 9 & 3 & 1 & 23 & & \\
\hline $31-40$ & 8 & 1 & 6 & 0 & 0 & 15 & & \\
\hline 41\&Above & 1 & 2 & 3 & 2 & 0 & 8 & & \\
\hline Total & 11 & 13 & 19 & 6 & 1 & 50 & & \\
\hline \multicolumn{9}{|c|}{ 3. I often complete my work within stipulated time } \\
\hline Age & SA & A & $\mathrm{N}$ & $\mathrm{DA}$ & SDA & Total & Chi-square & $\mathrm{P}$ value \\
\hline $22-25$ & 2 & 2 & 0 & 0 & 0 & 4 & \multirow{5}{*}{11.599} & \multirow{5}{*}{0.237} \\
\hline $26-30$ & 9 & 13 & 0 & 1 & 0 & 23 & & \\
\hline $31-40$ & 12 & 2 & 1 & 0 & 0 & 15 & & \\
\hline 41\&Above & 6 & 2 & 0 & 0 & 0 & 8 & & \\
\hline Total & 29 & 19 & 1 & 1 & 0 & 50 & & \\
\hline \multicolumn{9}{|c|}{ 4. I feel I am able to manage my family and other relationships well } \\
\hline Age & SA & A & $\mathrm{N}$ & DA & SDA & Total & Chi-square & $\mathrm{P}$ value \\
\hline $22-25$ & 2 & 2 & 0 & 0 & 0 & 4 & \multirow{5}{*}{6.340} & \multirow{5}{*}{0.386} \\
\hline $26-30$ & 6 & 15 & 2 & 0 & 0 & 23 & & \\
\hline $31-40$ & 8 & 5 & 2 & 0 & 0 & 15 & & \\
\hline 41\&Above & 5 & 2 & 1 & 0 & 0 & 8 & & \\
\hline Total & 21 & 24 & 5 & 0 & 0 & 50 & & \\
\hline \multicolumn{9}{|c|}{ Hinder in balancing your work and family commitments } \\
\hline \multicolumn{9}{|c|}{ 1. Negative attitude of management } \\
\hline Age & SA & A & $\mathrm{N}$ & DA & SDA & Total & Chi-square & $\mathrm{P}$ value \\
\hline $22-25$ & 3 & 0 & 1 & 0 & 0 & 4 & \multirow{5}{*}{12.794} & \multirow{5}{*}{0.384} \\
\hline $26-30$ & 4 & 14 & 3 & 1 & 1 & 23 & & \\
\hline $31-40$ & 7 & 5 & 2 & 0 & 1 & 15 & & \\
\hline 41\&Above & 3 & 2 & 2 & 1 & 0 & 8 & & \\
\hline Total & 17 & 21 & 8 & 2 & 2 & 50 & & \\
\hline \multicolumn{9}{|c|}{ 2. Negative attitude of colleagues } \\
\hline Age & SA & A & $\mathrm{N}$ & DA & SDA & Total & Chi-square & $\mathrm{P}$ value \\
\hline $22-25$ & 1 & 2 & 1 & 0 & 0 & 4 & \multirow{4}{*}{7.179} & \multirow{4}{*}{0.619} \\
\hline $26-30$ & 3 & 12 & 6 & 2 & 0 & 23 & & \\
\hline $31-40$ & 4 & 5 & 6 & 0 & 0 & 15 & & \\
\hline 41\&Above & 3 & 1 & 3 & 1 & 0 & 8 & & \\
\hline
\end{tabular}




\begin{tabular}{|c|c|c|c|c|c|c|c|c|}
\hline Total & 11 & 20 & 16 & 3 & 0 & 50 & & \\
\hline \multicolumn{9}{|c|}{ 3. Technology such as laptops/cell phones } \\
\hline Age & SA & A & $\mathrm{N}$ & DA & SDA & Total & Chi-square & $\mathrm{P}$ value \\
\hline $22-25$ & 1 & 0 & 1 & 1 & 1 & 4 & \multirow{5}{*}{14.208} & \multirow{5}{*}{0.288} \\
\hline $26-30$ & 4 & 11 & 3 & 4 & 1 & 23 & & \\
\hline $31-40$ & 1 & 4 & 4 & 6 & 0 & 15 & & \\
\hline 41\&Above & 2 & 2 & 3 & 1 & 0 & 8 & & \\
\hline Total & 8 & 17 & 11 & 12 & 2 & 50 & & \\
\hline \multicolumn{9}{|c|}{ 4. Travelling away from home } \\
\hline Age & SA & A & $\mathrm{N}$ & $\mathrm{DA}$ & SDA & Total & \begin{tabular}{|l|} 
Chi-square \\
\end{tabular} & $\mathrm{P}$ value \\
\hline $22-25$ & 0 & 2 & 1 & 0 & 1 & 4 & \multirow{5}{*}{11.958} & \multirow{5}{*}{0.449} \\
\hline $26-30$ & 3 & 4 & 12 & 3 & 1 & 23 & & \\
\hline $31-40$ & 5 & 4 & 6 & 0 & 0 & 15 & & \\
\hline 41\&Above & 1 & 2 & 3 & 1 & 1 & 8 & & \\
\hline Total & 9 & 12 & 22 & 4 & 3 & 50 & & \\
\hline \multicolumn{9}{|c|}{ 5. Extra Work Loads } \\
\hline Age & SA & A & $\mathrm{N}$ & DA & SDA & Total & \begin{tabular}{|l|} 
Chi-square \\
\end{tabular} & $P$ value \\
\hline $22-25$ & 2 & 1 & 0 & 0 & 1 & 4 & \multirow{5}{*}{20.255} & \multirow{5}{*}{0.062} \\
\hline $26-30$ & 7 & 11 & 4 & 1 & 0 & 23 & & \\
\hline $31-40$ & 10 & 3 & 1 & 1 & 0 & 15 & & \\
\hline 41\&Above & 2 & 5 & 1 & 0 & 0 & 8 & & \\
\hline Total & 21 & 20 & 6 & 2 & 1 & 50 & & \\
\hline \multicolumn{9}{|c|}{ 6. Unexpected responsibilities } \\
\hline Age & SA & A & $\mathrm{N}$ & DA & SDA & Total & Chi-square & $\mathrm{P}$ value \\
\hline $22-25$ & 1 & 0 & 2 & 0 & 1 & 4 & \multirow{5}{*}{17.717} & \multirow{5}{*}{0.125} \\
\hline $26-30$ & 3 & 7 & 9 & 3 & 1 & 23 & & \\
\hline $31-40$ & 7 & 4 & 4 & 0 & 0 & 15 & & \\
\hline 41\&Above & 3 & 4 & 0 & 1 & 0 & 8 & & \\
\hline Total & 14 & 15 & 15 & 4 & 2 & 50 & & \\
\hline \multicolumn{9}{|c|}{ 7. Forcing to Publish Research Works } \\
\hline Age & SA & A & $\mathrm{N}$ & DA & SDA & Total & Chi-square & $\mathrm{P}$ value \\
\hline $22-25$ & 0 & 3 & 1 & 0 & 0 & 4 & \multirow{5}{*}{9.196} & \multirow{5}{*}{0.419} \\
\hline $26-30$ & 3 & 11 & 8 & 1 & 0 & 23 & & \\
\hline $31-40$ & 5 & 8 & 2 & 0 & 0 & 15 & & \\
\hline 41\&Above & 0 & 4 & 4 & 0 & 0 & 8 & & \\
\hline Total & 8 & 26 & 15 & 1 & 0 & 50 & & \\
\hline \multicolumn{9}{|c|}{ Overall level of work life balance among working women faculties } \\
\hline Age & & gh & & lerate & Low & Total & Chi-square & $\mathrm{P}$ value \\
\hline $22-25$ & & 1 & & 2 & 1 & 4 & \multirow{5}{*}{1.616} & \multirow{5}{*}{0.951} \\
\hline $26-30$ & & 6 & & 1 & 6 & 23 & & \\
\hline $31-40$ & & 4 & & 9 & 2 & 15 & & \\
\hline 41\&Above & & 3 & & 4 & 1 & 8 & & \\
\hline Total & & 4 & & 26 & 10 & 50 & & \\
\hline \multicolumn{9}{|c|}{ Overall factors affecting work life balance } \\
\hline Age & & gh & & rate & Low & Total & Chi-square & $P$ value \\
\hline $22-25$ & & 2 & & & 2 & 4 & \multirow{5}{*}{8.086} & \\
\hline $26-30$ & & 3 & & & 5 & 23 & & \\
\hline $31-40$ & & 3 & & & 5 & 15 & & 0.232 \\
\hline 41\&Above & & 1 & & & 4 & 8 & & \\
\hline Total & & 9 & & & 16 & 50 & & \\
\hline
\end{tabular}

\section{Interpretation}

Since the $\mathrm{P}$ value is greater than 0.05 the null hypothesis is accepted at $5 \%$ level in majority of the factors. Hence concluding that there is no association between Age and level of work life balance among working women faculties, factors affecting work life balance. Based on the level of work life balance among working women faculties result, the respondents have strong 
positive opinion on they can devote sufficient time for household responsibilities and often complete my work within stipulated time and positive level of agreement on they feel are able to manage their family and other relationships well.

Since the $\mathrm{P}$ value is less than 0.05 the null hypothesis is rejected at $5 \%$ level. Hence concluding that there is an association between age and they can manage their personal \& professional life well, based on the results, respondents have neutral opinion on they can manage their personal \& professional life well.

On the basis of factors affecting work life balance results, the respondents have positive opinion on Negative attitude of management, Negative attitude of colleagues, Technology such as laptops/cell phones, Extra Work Loads, Unexpected responsibilities and Forcing to Publish Research Works and neutral level of agreement on Travelling away from home.

Since the $\mathrm{P}$ value is greater than 0.05 the null hypothesis is accepted at $5 \%$ level. Hence concluding that there is no association between Age and overall level of work life balance among working women faculties, Overall factors affecting work life balance. The respondents have moderate level of agreement towards overall level of work life balance among working women faculties, Overall factors affecting work life balance.

\section{FINDINGS}

- Majority of the respondents are in the age group in 22-25 years, working as an assistant professor, qualified of Doctor Philosophy and earning 50,001 to 1, 00,000 per month.

- The results found that the respondents have strong positive opinion on they can devote sufficient time for household responsibilities and often complete their work within stipulated time and positive level of agreement on that they feel they are able to manage their family and other relationships well.

- It is found that respondents have neutral opinion on they can manage their personal \& professional life well.

- The respondents have positive opinion on Negative attitude of management, Negative attitude of colleagues, Technology such as laptops/cell phones, Extra Work Loads, Unexpected responsibilities and Forcing to Publish Research Works and neutral level of agreement on Travelling away from home.

- The respondents have moderate level of agreement towards overall level of work life balance among working women faculties, Overall factors affecting work life balance.

\section{CONCLUSION}

Work-life balance is an issue of great importance that has to be addressed by the organizations at the earliest. After all the employees are the greatest asset and the organization performance is affected by employee performance. The organization and the employees together must work out strategies to help attain Work-life balance which makes the organization the happiest place to work in. In spite of higher salaries and other monetary and non monetary benefits, a comfortable working environment, less work load and organizations taking care of employees, it is observed that sometimes employees fail to deliver expected sales. Though there can be numerous factors that affect the performance of an employee achieving balance in work and familial life is considered important in order to perform par excellence. Balance between professional and personal life improves performance at work and also helps in gaining job satisfaction. It gives a feeling of contentment and motivates the individual to shoulder responsibilities with greater accountability. It helps in creating a congenial environment at the work place and also strengthens family bonds of the employees. 


\section{REFERENCES}

[1] Sandhya P.S and Sri Ranjini S, The Impact of Microfinance through Self-Help Groups (SHG): A Study on the economic status of urban women working in Production and Manufacturing Industries in Mysuru District, International Journal of Mechanical Engineering and Technology 9(1), 2018. pp. 472-481

[2] Raghavendra $\mathrm{H} \mathrm{K}$ and Raghunandan $\mathrm{M}$ V, Women Engineers and Work Life Balance A case study of Women working in Manufacturing Industries in Mysuru City, International Journal of Mechanical Engineering and Technology 9(1), 2018. pp. 752755

[3] Dr. R. Rajkumar. Work Life Balance Training - Does It Works for It Employees. International Journal of Management, 7(2), 2016, pp. 572-577.

[4] A. Rashida Banu, K. Duraipandian, Development of an Instrument to Measure Work Life Balance of it Professionals in Chennai, International Journal of Management (IJM), Volume 5, Issue 11, November (2014), pp. 21-33

[5] N. Mohan, N. Prabha and P. Mohanraj, Work Life Balance through Flexi Work Arrangements: Empirical Study on Bank Employees, International Journal of Management (IJM), Volume 1, Issue 2, July-August 2010, pp. 53-61 